\title{
A Structural Case for International Cooperation
}

\author{
Amelia Correa and Romar Correa \\ University of Mumbai
}

\begin{abstract}
We recommend a Bretton Woods system along structural lines. A key component of the case is the substitution of the money transmission mechanism by the credit transmission mechanism. We suggest that the real exchange rate be the variable of cooperation between countries that are free to set interest rates to pursue domestic policy objectives.
\end{abstract}

- JEL Classifications: E12, F41, F42

- Key words: Bretton woods system, Money transmission mechanism

\section{Introduction}

This essay is written against the aftermath of a financial crisis-ridden world. The novelty in the spate of meltdowns that devastated the Asian economies in the late nineties is the pivotal role that banks had to play in the vicious spirals. Earlier, financial markets in these countries had been extensively liberalised in order to attract capital inflows for the purpose of promoting rapid economic growth. A large component of these transfers arrived in the form of foreign bank lending. Unsurprisingly, foreign lenders were ignorant of the nuances of projects that they were financing. They rationalised their lending on the basis of economy-wide statistics and the expectation that their loans were guaranteed, in dollar terms, by the respective governments. In many of these countries, the borrowing was substantially by local banks. These banks assumed that exchange rates were fixed in the short run and consequently there was no exchange rate risk to be borne. A lending bubble in land, rents and stocks ensued. As long as the prices of these

*Corresponding address: Prof Romar correa, Departmant of Economics University of Mumbai Vidyanagari Munbai 400098 India. E-mail: romar77@hotmail.com (C2003-Center for International Economics, Sejong Institution, All Rights Reserved. 
assets rose and the exchange rate was fixed the balance sheets of the local intermediaries appeared sound. They continued to underwrite risky investments with low and even negative expected returns.

Fixed exchange rates had an important role to play in the crises that followed. Countries basically pegged their currencies to the US dollar. The manifestation was short-term capital inflows. The inducement to borrow excessively abroad at lower foreign interest rates was heightened. Currencies became overvalued both because of the appreciation of the US dollar relative to the yen and the lower rate of US inflation. The overvalued currencies progressively led to deteriorating trade balances and eventually unsustainable current account deficits. The latter had been financed not by FDI but by short-term debt. In the end the combined foreign exchange reserves of the central banks and the financial intermediaries fell far short of the maturing debt. Institutions were unable to honour their foreign obligations. The rational response was speculation. As the breakdowns loomed, the fixed interest rates constrained the capacity of the countries to raise domestic interest rates. It is important to note that twin banking and currency crises are more severe in terms of positive feedback and negative multiplier effects than either crisis alone. When domestic banks have large net liabilities to foreigners denominated in foreign currencies, a major devaluation threatens their liquidity and even their solvency. Banks call in loans and cut back on fresh project financing. The causal arrows can move both ways. A dollar liquidity problem in the banking system aggravates a currency crisis. The adverse impact on output is more pronounced when banks are the prime source of credit

A key lesson of the Bretton Woods debate has been ignored. Parities are not immutable but must be adjusted in response to macroeconomic fundamentals. With fixed parities there is a unique relationship between the domestic price level and the price in the rest of the world, that is, a unique real exchange rate which is consistent with free capital movements, balance of payments equilibrium and full employment. The movement of capital worldwide benefits all countries through the transfer of real resources from surplus countries to deficit countries. Social yields are equalised. However, if countries are to retain the ability to pursue domestic employment objectives in regimes of generalised price rigidities, longrun flexibility in exchange rates is a sine qua non. Economic policies in sovereign states will diverge and parities must adjust to permit the current account to balance in order to effect the requisite real flows.

A formal way to model all this would be the workhorse of international 
macroeconomic theory, the Mundell-Fleming model. The model is the openeconomy version of the IS/LM framework. Accordingly, the demand for and the supply of money is an integral component of the model. Money is exogenous. In the open-economy extension, the exogeneity of the money supply goes with the endogeneity of the exchange rate. Conversely, it is argued, if the exchange rate is fixed, monetary authorities lose control over the domestic money supply. However, the LM curve has been banished from current discussions of macroeconomic theory and policy. The reasons have to do with the workings of both blades of the Marshallian scissors as they apply to the money market. On the one hand, instability of demand for money functions is spreading. On the other, financial innovations and/or progressive financial liberalization has resulted in the controllability of the money supply being called into question. In the next section we provide, in the spirit of David Romer, a Mundell-Fleming model without the LM curve. Some motivation is provided by the recent pronouncement by Richard Cooper that "resolution of exchange rate choices have been inhibited by the continuing use of by the economics profession of an extraordinarily primitive theory of money in its theorizing" [Sneddon-Little and Olivei, 1999]. For ease of exposition we make some simplifying assumptions like money is endogenous. At any rate, another shared belief is that central banks worldwide do/should use shortterm interest rates rather than the money stock as a control variable. In that case, we propose that the familiar dichotomy cited above does not apply. The authorities can both control interest rates and the exchange rate.

The opening of the IS/LM model is accomplished by a few parity relationships. They include the (un)covered interest parity equation (UIP) and purchasing power parity (PPP). Both these relationships have had a troubled empirical history. The econometric sophistication exercised in order to validate the theory of (long-run) purchasing parity theory (PPP) is well known. All tests suggest that the theory has no basis in reality. A recent exercise conducted over two centuries for the dollarsterling exchange rate concludes as much [Cuddington and Liang, 2000]. Secondly, the times are characterised by a furious pace of financial innovations. Capital mobility is increasing rapidly and, therefore, capital markets are being integrated worldwide. Jan Marc Berk and Klaas H.W. Knot [2001] ask whether the increased capital mobility has resulted in a greater validation of UIP. A test of the relationship is conducted for bond-yield differentials vis-a-vis the US, Germany, France, the UK, Switzerland and Japan with the aid of PPP-based exchange rate expectations against the US dollar. The authors find no support for any increased 
tendency towards a co-movement of bond yields. Indeed, summarising the available evidence, the authors conclude that not only do actual exchange rates not move one-to-one with interest rate differentials but the relationship is perverse. The changes are substantial and opposite to that suggested by UIP! In what follows we write an open-economy model that does not require these two relationships.

\section{Structural Open-Economy Macroeconomics}

The structural approach asserts that macroeconomic structures as given by a system of equations are fundamental. They possess causal powers and transmit causal efficacy. The simultaneous equations may be regarded as a network of counterfactual relations that delivers variables that can be manipulated as well as the typical asymmetry of causal relations. Macroeconomic aggregates supervene upon microeconomic behaviour [Hoover, 2001]. This is taken to mean that two economic structures with an identical configuration of individual elements will possess the same macroeconomic characteristics. It is not true, however, that the same system of macroeconomic relations entails the identical pattern of microeconomic components. Hoover [2001] applies the general strategy to model money, prices and interest rates in the US from 1950 to 1985. The results are largely anti monetarist. Monetarism is understood in the sense of Friedman as including the following propositions: the money supply is exogenous and controllable by the monetary authorities; the demand for money is stable and the short-run channels connecting money to prices and output are direct and not mediated through financial markets. He finds that money does not cause prices but prices cause money. We require the following definitions [Simon 1997A, 1997B]:

DEFINITION 1. A linear self-contained structure is an $n \times n$ matrix of 0's and 1 's such that 1's appear in all the columns.

DEFINITION 2. A minimal self-contained subset is a subset of the rows of a self-contained structure such that the subset is self-contained but does not itself include a self-contained proper subset.

Further elaboration of the conceptual apparatus is best conducted in the context of our specific structure. We consider a world with one good and two assets, deposits (money) and loans. There are three agents, households, firms and banks. 
Superscripts $h, f$ and $b$ respectively, distinguish them The real income of households $y$ and the interest rate on deposits $r_{D}$ determine savings $S$. Banks are profit maximisers operating on both sides of their balance sheets. The investment demand $I$ of firms is satisfied by bank loans at a price $r_{L}$. Therefore, the IS curve is

$$
I\left(r_{L}\right)=S\left(y, r_{D}\right)
$$

The conditions for loan market and deposit market clearing are given, in turn, by

$$
L^{f}\left(r_{L}\right)=\underset{+}{b}\left(r_{L}\right)
$$

and

$$
\left.D^{h} \underset{+}{\left(y, r_{D}\right.}\right)=D^{b}\left(r_{-}\right)
$$

The system of equations above defines the following structure. The three rows signify the three equations or mechanisms. The variables are displayed as columns.

$\begin{array}{cccc} & \mathrm{y} & \mathrm{r}_{\mathrm{L}} & \mathrm{r}_{\mathrm{D}} \\ \text { E1 } & 1 & 1 & 1 \\ \text { E2 } & 0 & 1 & 0 \\ \text { E3 } & 1 & 0 & 1\end{array}$

The second equation is a minimal self-contained structure. The system therefore defines the following causal ordering among the variables

$$
r_{L} \rightarrow\left\{y, r_{D}\right\}
$$

The loan rate of interest is an exogenous variable in the sense that it is determined in a larger system of which the present structure is a section [Papandreou, 1962]. The solution of an exogenous variable is itself determined in a self-contained structure which is the complement of the present structure. Thus we treat the three-equation model above as the non-self-contained proper subset of an unarticulated causal structure. An exogenous variable suggests the manipulation of the effects by the policy maker as well as the time precedence of the variable in question [Simon, 1997B]. Time precedence is necessary, but not 
sufficient, for causality. The causal attribution at the macroscopic level rests upon assumptions that there exists a plausible theory explaining the connections at a microscopic scale. In the present instance, the direction of causation is consistent with the 'old' credit view, sometimes associated with Schumpeter, which suggests that the supply of credit is highly responsive to loan demand at given rates of interest [Trautwein, 2000]. The money multiplier is important although the causal arrows work in reverse. Loans make deposits and deposits make reserves redundant by the institution of interbank clearing which helps banks expand their loans further.

The open-economy counterpart of the above model, and excluding the familiar parity relationships for reasons given in the previous section, follows. Stars on variables denote foreign magnitudes. Recall that an important inclusion is net exports $X$ and the real exchange rate, $q$, defined here in logarithms. The price levels are denoted in the usual way and $s$ is the nominal exchange rate. We have

$$
\begin{aligned}
& \left.\underset{+}{S\left(y, r_{D}, r_{D}^{*}\right.}\right)=I\left(r_{L}, r^{*}{ }_{-}\right)+X\left(q, y, y_{+}^{*}\right) \\
& q=s-\left(p-p^{*}\right) \\
& L^{f}\left(r_{L}, r_{L}^{*}\right)=L^{b}\left(r_{L}, r_{L}^{*}\right) \\
& D^{h}\left(\underset{++r_{+}}{y, r_{d}, r_{D}^{*}}\right)=D^{b}\left(r_{D}, r_{-}^{*}\right)
\end{aligned}
$$

In keeping with the Keynesian flavour of the model we assume that the two price levels are exogenous. In the language of the present presentation, it can be said that each of the two price levels are endogenous in two self-contained structures. The real exchange rate is the new structural variable. Note that the nominal exchange rate cannot fulfill this role as it would not fulfill the requirements of Definition 1 . Some recent empirical validation can be provided by the experience of countries that sought to reduce domestic inflation by introducing a fixed exchange rate with the US [Askari, 1999]. In the case of Chile and Mexico a predetermined nominal crawling peg was adopted. The real sector was ignored. The outcome was that the inflation rates did not converge. Real exchange rates became overvalued and there was a loss in competitiveness. In contrast, the program implemented in Argentina in 1991 resulted in deflation and an inflation rate that was systematically lower than that of the US. The explanation is the 
strong cooperation between the ruling political party and the trade unions that led to moderation in wage demands that halted the galloping inflation.

$\begin{array}{lcccc} & \mathrm{y} & \mathrm{r}_{\mathrm{L}} & \mathrm{r}_{\mathrm{D}} & \mathrm{q} \\ \text { E1 } & 1 & 1 & 1 & 1 \\ \text { E2 } & & & & 1 \\ \text { E3 } & & 1 & & \\ \text { E4 } & 1 & & 1 & \end{array}$

There are two minimal self-contained structures which give the following causal ordering.

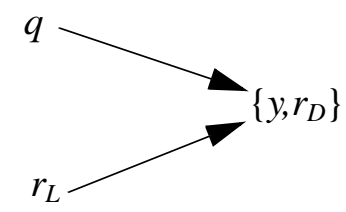

The implication is that countries coordinate on the real exchange rate and use the domestic banking system for credit expansion. The evidence suggests that this is indeed that case [Aizenman and Hausman, 2000]. Producers anywhere rely solely on credit to satisfy their working capital needs. Loans are forthcoming mainly from domestic sources which are segmented from international markets due to country-specific risks chief among which is exchange rate uncertainty. A desirable objective then is the reduction of exchange rate flexibility which is likely to reduce the real exchange rate. The result has usually been a sharp drop in interest rates [Dornbusch, 2001]. In addition, particularly in bank-mediated regimes, there is a reinforcement of the disbursal of credit and a lengthening of the horizons of economic agents. With low and stable inflation, there is an increase in investment and risk-taking. The eventual outcome is higher growth.

Even when all the prudential regulations are in place, banks are ill-equipped to handle certain types of systemic risk. A familiar category of risk that has been investigated is precisely real exchange rate risk [Kildegaard and Williams, 2002]. The problem lies in the essential nature of the bank covenant which is an option for the borrower. In the event of good states of the world, the borrower harvests all the benefits in excess of the interest rate; in the event of the alternative, she may renege on repayment. One solution to the problem is for banks to diversify real exchange rate risk by insisting upon diversification by each borrower. In the study 
quoted the prediction is, therefore, that vertical integration should be higher in bank-based systems. If banks cannot take equity stakes in different sectors, they insulate themselves from real exchange rate shocks by inducing borrowers to take equity stakes in each other. The integration is across the tradeables/non-tradeables divide. A common measure of the real exchange rate is the ratio of the producer price index to the consumer price index since non-traded elements have a relatively larger weight in the latter. For any producer manufacturing either the non-traded final good or the traded final good, with a mix of both in the input bundle, the optimal policy is vertical merger in order to achieve the desired level of diversification. A real exchange rate shock would redistribute income in a lumpsum transfer from non-tradeable goods producers to tradeable goods producers, from one class of bank borrowers to another. The theory fits the data best when run over a sub-sample of middle-income countries and over the sub-samples of the Materials and Services sector.

\section{Keynes and after: The Circuit Approach}

The origins of the framework above can, expectedly, be traced to Keynes. The architecture of A Treatise on Money, for example, is founded on the assumption that the money in the hands of the public is bank money [The Collected Writings of John Maynard Keynes, Vol. VI, 1971B]. The control of prices is, he argued, exercised through the control of the rate of investment. The problematic of the system is the preservation of the balance between the rate of saving and the value of new investment through the creation of credit which is non-profit-inflationary. The price level of output depends on the level of money incomes relative to efficiency, on the volume of investment relative to saving supply and on the animal spirits of entrepreneurs relative to the deposits available in the banking system. Banks can control the supply of deposits and influence the volume of investment by the terms of credit. Thereby they indirectly determine the money offers made by entrepreneurs to the factors of production.

The open-economy counterpart to the argument can be found in A Tract on Monetary Reform [The Collected Writings of John Maynard Keynes, Vol. IV 1971A]. Keynes makes the case for "stability of prices" against the "stability of exchange" [Keynes, 1971A, p.125]. Since the rate of exchange of the currencies of two countries depends upon the relationship between the domestic price level and the foreign price level, the exchange rate can be stable only if both the internal and 
the external price level remain stable. Stability of exchange is no more than a convenience for traders. Contracts and expectations formed on the basis of stable exchange are fewer than those that presume a stable domestic price level. The main objective of an international currency system is a control mechanism for countries that do not maintain the stability of domestic efficiency costs and do not move cooperatively on national wage policies [The Collected Writings of Keynes, Vol. XXVI 1980].

Followers of Keynes expand on the role of the monetary authorities explicitly [Lavoie, 2000]. Central banks set short-term nominal interest rates and inflation rates are given in the short run. It is therefore possible for a central bank to set the short-term real interest rate which is different from the real rates prevailing elsewhere. The logic extends to the forward exchange market. The spread between forward and spot exchange rates are set by dealers on the basis of interest rate differentials on the euro-currency markets that are accessible to the financial intermediaries. Covered interest parity holds trivially. Banks equilibrate the forward exchange market by covering the excess forward orders on the spot market. They borrow the currency which is sold and lend the currency which is bought. They make a profit by charging customers forward rates which reflect the interest rate differential. Suppose that speculators decide to sell the domestic currency forward. Banks will cover themselves by selling the domestic currency spot. This will immediately impact on the spot rate or on foreign reserves. Central bank interventions can counter the sale of domestic currency on the spot market without an immediate loss of foreign exchange. These operations will have no impact on the forward-spot differential unless accompanied by discretionary changes in relative interest rates. Only uncovered forward operations induce inflows and outflows. These can be countered by forward exchange market purchases and sales by the central bank.

Suppose that a central bank were to administer a low real interest rate structure. Short-term investors would be tempted to invest abroad. The outcome would be either a depreciation or a balance of payments deficit. If a depreciation were the result, there would be pressure on the inflation rate and real rates would move downwards. In our model there is no endogenous reduction in the monetary base or in the money supply. Government deficits or a favourable balance of payments have no direct impact on the creation of money for any such money created is compensated by an equivalent reduction in credit money.

Indeed, there exists a coherent structure in the Schumpeter-Keynes tradition, 
due largely to the efforts of French and Italian scholars, the circuit approach, that models the sequence in the argument outlined above [Parguez, 1996]. The monetary circuit is an ordered recursive structure explaining the present conjuncture by data that include the fruits of past decisions and the constraints under which firms must operate as well as the profit expectations of firms. The first stage of the circuit is the capital value or asset price of the firm which is the assessment by the market of the flow of net revenue of the firm. There is a value of the firm (expressed in money terms) that is a target insofar as it is consistent with the appraisal of its bank of the ability of the firm to meet its contractual obligations. Banks would regard this required capital value as the collateral for their loans. Credibility is ensured by the rate of return on their costs of production that will generate short-run profits earned on current sales. In that case, banks are fully committed to sanctioning the liquid fund required by the firm to carry out its production plans. In the terms of our model, $L^{b}=L^{f}$. This fund is created in the form of deposits, $D^{b}$, which mean an increase in the liabilities of the banking system. These deposits can be freely transferred to households as wages or to producers of investment goods as receipts.

The next stage of the circuit is the repayment of debts based on the success of firms in generating income. Household income is aggregate wages and mirrors the purchasing power over the current supply of consumption goods. Another portion of the initial liquid fund must be invested in the output of investment goods producers. The familiar identities are receipts of consumption goods producers are generated by households' expenditures which equal the excess of the aggregate wage bill over household savings. The gross income of equipment goods producers is the quantum of aggregate investment, their own purchase of investment goods plus the acquisition of equipment goods by consumption goods producers.

In the final stage firms can repay their debts to banks by an amount equal to their gross income. The ratio of current net income to investment expenditures indicates the share that is paid back by the flow of current profits, the effective rate of internal finance. The stage is set for a new circuit.

Savings in the circuit is both real saving and financial saving. Real saving is the increase in real wealth generated by the circuit process. It is the value of the stock of equipment providing output in future that should be validated by the corresponding demand and thereby generate revenue. It is identical to the aggregate capital value of the set of firms owning and using this equipment. Real 
saving is thus identical to real investment. Financial saving is the excess of aggregate income over consumption expenditures. It is that share of aggregate income that must be spent by providing funding for investment initiated by bank advances. Aggregate income is the sum of wages and profits. Wages and consumption being equal, financial saving equals aggregate profits equals aggregate investment. Firms, in the aggregate, generate a quantity of saving which matches the debts incurred in the investment process which is equal to that amount of saving.

Interest payments are a drain on aggregate profits. Profits are distributed between firms and banks (and workers). Interest payments are the part of the initial credit injection that firms cannot pay back from their gross income that is generated by sales. For the sake of consistency of the framework, banks are committed to finance this deficit by recycling their profits on the stock exchange. Within each circuit, banks recycle their interest income by acquiring shares issued by firms as the financial counterpart of their investment. Thus firms can write off their initial credit and banks can accumulate net wealth which supports their own capital values. The process is consistent with the $S=I$ relation. A basic proposition here is that no free fund for investment can originate in the market for claims. Shares are bought and sold because of the prior existence of profits to be spent. These profits are not generated in financial markets but by credit-financed investment.

In a not dissimilar manner, savings are an uncompensated leakage in the process of generating gross income accruing to consumption goods producers. The savings of wage-earners must be parked in the acquisition of available debt or titles to wealth. The only source of these titles, directly or indirectly, is the gross deficit firms are pledged to finance by writing off their short-run debts. There is thus a required equality between the savings of workers and the gross deficit it initiates. As long as the economy is not a pure rentier economy, the value of the increase in financial wealth equals the increase in real wealth equals investment expenditure. Investment generates an equal amount of financial saving which is divided between firms, banks and wage-earners. A 'shortage of saving' cannot occur. Any shortfall of investment must be seen as a lack relative to the requirements of full employment. It is seen that the liquidity preferences of households do not matter. Households do have a choice between purchasing direct claims on firms and direct claims on banks, $D^{h}$. In the first case, the investment leads to a reduction in the gross deficit pari passu. What remains is the ultimate 
deficit which is equal to the share of their savings that households want to invest in claims on lending banks. In the interest of closure once again, banks are committed to channelising this saving into refunding the remaining deficit.

In order to extend the circuit approach to the international sphere it is worthwhile to record that all contemporary participants in the fixed versus flexible exchange rates debate are unanimous that the conflict is misspecified. Robert Mundell puts it pithily: fixed and flexible exchange rates are an oxymoron [Mundell, 2001]. The appropriate choices lie elsewhere. In the language of the circuit school, both regimes are relative exchange rate regimes [Cencini, 1995]. Both nationally and internationally, domestic currencies are identified with net assets so that the exchange between commodities and money and that between monies pertain to the realm of relative exchanges. Both regimes are comparable because currencies are regarded as synonymous with goods and are dependent on the forces of supply and demand.

The classical-Keynes approach advocated here, on the other hand, has been called a system of absolute exchanges by Bernard Schmitt [Cencini, 1995]. Money plays a purely circular or vehicular role. It is bank money without any intrinsic value and does not define a final payment. In every international payment, the creditor country obtains, in the first step of the sequence, no more than a promise of repayment. The payment becomes effective only at the moment that the money is returned to the debtor country in exchange for its real content. International currencies are real and currencies are not the object of an independent demand. Consider the case of country $A$ exporting to the US. Under either a fixed or flexible exchange rate system, a demand for say Euros is defined and exchange between a quantity of $A$ goods and an equivalent sum of American dollars takes place. In the light of the model under consideration, however, the dollars are simultaneously supplied and demanded by country $A$ since the US's effective payment for the goods takes place through the transfer of an equivalent sum of American bonds which are claims to commodities. Dollars circulate back to their point of origin. The American dollar is no more than a promise to pay and corresponds to goods and services. In the circular flow the American currency demanded and supplied has no impact on the value of the respective currencies. Exchange rates are fixed in this sense. Dollars are changed into Euros the moment $A$ 's exports are purchased, to be changed into dollars at the point that the same American bonds are used for final payment. Imports are covered by equivalent exports when the balance of trade is in equilibrium or bonds in the case of a trade deficit. A system 
of absolute exchange rates would provide no vent for speculative forces because there would be no impulse to accumulate foreign exchange. If internal disequilibria persisted, the level of absolute exchange rates would have to be modified.

\section{Conclusion}

Banks have emerged as critical players in the world and correspondingly there have been attempts to investigate, for example, the liquidity preference of banks rather than the preferences of the representative agent in macroeconomic models. Nowhere are banks completely uncontrolled but are always under the prudential surveillance of the monetary authorities. It is also the case that for reasons to do with risk and fundamental uncertainty the usual parity relationships that are employed in models of interacting countries do not hold. The suggestion then is to think less in terms of corner solutions given by the famous impossibility theorem of open-economy macroeconomics and more in terms of interior solutions [Frankel, 1999]. Countries can, to their mutual benefit, control both the real exchange rate and domestic interest rates.

\section{Acknowledgements}

The comments of an anonymous reviewer on a first draft are gratefully acknowledged. We alone retain full responsibility for the final product.

Received 12 July 2001, Accepted 11 June 2002

\section{References}

Aizenman, Joshua and Ricardo Hausman [2000], "Exchange Rate Regimes and Financial Market Imperfections", NBER Working Paper.

Askari, H. [1999], "Twenty-five years of Post-Bretton Woods experience: some lessons", Banca Nazionale del Lavoro Quarterly Review, 22, 3-38.

Berk, Jan Marc and Klaas H.W. Knot [2001], "Testing for long horizon UIP using PPPbased exchange rate expectations", Journal of Banking and Finance, 25, 377-391.

Cencini, Alvaro [1995], Monetary Theory, London: Routledge.

Cuddington, John T and Hong Liang [2000], "PPP over two centuries?", Journal of International Money and Finance, 19, 753-757. 
Dornbusch, Rudiger [2001], "Fewer Monies, Better Monies", American Economic Review, 91, 238-242.

Frankel, Jeffrey A. [1999], "No Single Currency Regime is Right for all countries or at all times", NBER Working Paper.

Hoover, Kevin D. [2001], Causality in Macroeconomics, Cambridge: Cambridge University Press.

Keynes, John Maynard [1971A], A Tract on Monetary Reform, in: The Collected Writings of John Maynard Keynes, Volume IV, London: Macmillan.

[1971B], A Treatise on Money 2: The Applied Theory of Money, in : The Collected Writings of John Maynard Keynes, Volume VI, London: Macmillan.

[1980], "The Objective of International Price Stability", in: The Collected Writings of John Maynard Keynes, Volume XXVI, London: Macmillan: 3033.

Kildegaard, Arne and Pete Williams [2002], "Banks, systematic risk and industrial concentration", Journal of Economic Behavior and Organization, 47, 345-358.

Lavoie, Marc [2000], "A Post Keynesian view of the interest parity theorem", Journal of Post Keynesian Economics, 23, 163-179.

Mundell, Robert Alexander [2001], "Currency Areas and International Monetary Reform at the Dawn of a New Century", Review of International Economics, .9, 595-607.

Papendrou, Andreas G. [1966], Fundamentals of Model Construction in Macroeconomics, Athens: C. Serbinis Press.

Parguez, Alain [1996], "Beyond Scarcity: A Reappraisal of the Theory of the Monetary Circuit", in: Money in Motion, eds. Ghislain Deplace and Edward J. Nell, London: Macmillan: 155-199.

Simon, Herbert A. and Yumi Iwasaki [1997A], "Causal Ordering, Comparative Statics and Near Decomposability", in: Models of Bounded Rationality, Volume 3: Empirically Grounded Economic Reason, Cambridge: The MIT Press: 13-41.

[1997B], "Causality with Model Abstraction", in: Models of Bounded Rationality, Volume 3, Empirically Grounded Economic Reason, Cambridge: The MIT Press : 43-104.

Sneddon-Little, Jane and Giovanni P. Olivei [1999], "Rethinking the International Monetary System: An Overview", New England Economic Review, Novermber/ December, 3-24.

Trautwein, Hans-Michael [2000], "The Credit View, Old and New", Journal of Economic Surveys. 14, 155-189 